\title{
HUBUNGAN PEMBERIAN STIMULASI DENGAN PERKEMBANGAN BALITA USIA 1-5 TAHUN DI POSYANDU SERUNAI VII KELURAHAN VI SUKU WILAYAH KERJA PUSKESMAS TANAH GARAM KOTA SOLOK
}

\author{
AFRIDON \\ Akademi Keperawatan YPTK Solok
}

\begin{abstract}
Factors affecting growth and development are genetic, environmental (prenatal, and post natal), post-natal environments that affect children's growth and development in general can be classified as biological environments. One factor that influences development is stimulation. The type of research used is descriptive analytic with Cross Sectional Study design in which to see the relationship between two variables. The variable in this study is the independent variable is the provision of stimulation and the dependent variable is the development of toddlers aged 1-5 years. Based on the results of research conducted on 34 respondents, it is known that more than a portion (64.7\%) of respondents provide developmental stimulation in infants, more than a portion (61.8\%) of infants of respondents have appropriate development and analysis results between the provision of stimulation and development under-five children were found to be more than a part (66.7\%) who did not provide stimulation that experienced dubious development. While statistically obtained $p$ value $=0.025<$ 0.05, which means that there is a significant relationship between those who do not provide stimulation with the development of children who have doubts. It is expected that health workers provide information on how to provide stimulus to their toddlers in accordance with the stage of development of their age so that respondents are able to provide stimulus to their children
\end{abstract}

Keywords: Stimulation, Toddler Development

\section{A. Pendahuluan}

Pembangunan kesehatan sebagai bagian dari upaya pembangunan manusia seutuhnya antara lain diselenggarakan melalui upaya kesehatan anak yang dilakukan sedini mungkin sejak anak masih didalam kandungan. Upaya kesehatan yang dilakukan sejak anak masih dalam kandungan sampai lima tahun pertama kehidupannya, ditujukan untuk mempertahankan kelangsungan hidupnya sekaligus meningkatkan kualitas hidup anak agar mencapai tumbuh kembang secara optimal baik fisik, mental emsional maupun sosial serta memiliki inteligensi majemuk sesuai dengan potensi genetiknya.

Anak merupakan individu yang unik, dimana mereka mempunyai kebutuhan yang berbeda-beda sesuai dengan tahapan usianya, anak bukan miniatur dari orang dewasa atau orang dewasa dalam tubuh yang kecil, untuk itu perlu diperhatikan pertubuhan dan perkembangan anak. Perkembangan merupakan perubahan-perubahan pada tubuh seseorangyang tidak dapat diukur, perubahn ini terjadi secara bertahap sehingga kemampuannya selalu bertambah.

Faktor yang mempengaruhi tumbuh dan kembang adalah faktor genetik, lingkungan (lingkungan pranatal, dan post natal), lingkungan post natal yang mempengaruhi tumbuh kembang anak secara umum dapat digolongkan menjadi lingkungan biologis. Menurut WHO, prevelensi balita pendek menjadi masalah kesehatan masyarakat jika prevelensinya $20 \%$ atau lebih, di Indonesia prevelensi balita pendek masih tinggi dan merupakan masalah kesehatan yang pelu ditanggulangi, berdasarkan survey yang dilakukan terhadap deteksi dini balita di Puskesmas yang ada 
di Kota Solok, dimana di Puskesmas Tanah Garam terdapat adanya gangguan perkembangan pada anak, Tumbuh kembang perlu dipelajari supaya ibu balita mengetahui dan memahami proses pertumbuhan dan perkembangan yang normal sehingga dapat mendeteksi kelainan yang terjadi pada proses pertumbuhan dan perkembangan secara dini.

\section{B. Metode Penelitian}

Jenis penelitian yang digunakan adalah deskriptif analitik dengan desain Cross Sectional Study dimana untuk melihat hubungan antara dua variabel. Variabel dalam penelitian ini adalah variabel independen dan dependen, yang menjadi variabel independen adalah pemberian stimulasi dan variabel dependen adalah perkembangan balita usia 1-5 tahun.

\section{Hasil Penelitian dan Pembahasanlah \\ 1. Hasil}

Karakterisitik Responden

\section{a. Pendidikan}

Tabel 1

Distribusi Frekuensi Responden Berdasarkan Tingkat Pendidikan di Posyandu Serunai VII Kelurahan VI Suku Wilayah Kerja Puskesmas Tanah Garam Kota Solok

\begin{tabular}{|c|c|c|c|}
\hline No & Pendidikan & $\mathbf{f}$ & $\%$ \\
\hline 1 & Pendidikan dasar (SD- & 14 & $41,2 \% \%$ \\
\hline 2 & SMP) & 18 & $52,9 \%$ \\
\hline 3 & $\begin{array}{l}\text { Menengah (SMA) } \\
\text { Tinggi (PT) }\end{array}$ & 2 & $5,9 \%$ \\
\hline & Jumlah & 34 & 100 \\
\hline
\end{tabular}

Berdasarkan tabel diatas diketahui bahwa lebih dari sebagian $(52,9 \%)$ responden berpendidikan menengah (SMA).

b. Pekerjaan

Tabel 2

Distribusi Frekuensi Responden Berdasarkan Jenis Pekerjaan di Posyandu Serunai VII Kelurahan VI Suku Wilayah Kerja Puskesmas Tanah Garam Kota Solok

\begin{tabular}{|c|c|c|c|}
\hline No & Pekerjaan & f & $\%$ \\
\hline 1 & IRT & 26 & $76,5 \%$ \\
\hline 2 & Pedangan & 1 & $2,9 \%$ \\
\hline 3 & Petani & - & - \\
\hline 4 & Swasta & 1 & 2,9 \\
\hline 5 & PNS & 6 & $17,6 \%$ \\
\hline \multicolumn{2}{|r|}{ Jumlah } & 34 & 100 \\
\hline
\end{tabular}

Berdasarkan tabel diatas diketahui bahwa lebih dari sebagian $(76,5 \%)$ responden bekerja sebagai ibu rumah tangga (IRT). 


\section{Hasil Penelitian}

\section{a. Hasil Univariat}

\section{Pemberian Stimulasi}

Distribusi Frekuensi Responden Berdasarkan Pemberian Stimulasi

Perkembangan pada Balita di Posyandu Serunai VII

Kelurahan VI Suku Wilayah Kerja Puskesmas Tanah Garam Kota Solok

\begin{tabular}{|l|l|l|ll|}
\hline No & Pemberian Stimulasi & $\mathbf{f}$ & \% & \\
\hline 1 & Diberikan & 22 & $64,7 \%$ & \\
2 & Tidak diberikan & 12 & $35,3 \%$ & \\
\hline \multicolumn{2}{|c|}{ Jumlah } & \multicolumn{2}{|c|}{$\mathbf{3 4}$} & \multicolumn{2}{|c|}{$\mathbf{1 0 0}$} \\
\hline
\end{tabular}

Berdasarkan tabel diatas diketahui bahwa lebih dari sebagian $(64,7 \%)$ responden memberikan stimulasi perkembangan pada balita di Posyandu Serunai VII Kelurahan VI Suku Wilayah Kerja Puskesmas Tanah Garam.

Perkembangan Balita

Distribusi Frekuensi Responden Berdasarkan Perkembangan Balita di Posyandu Serunai VII Kelurahan VI Suku Wilayah Kerja Puskesmas Tanah Garam Kota Solok

\begin{tabular}{|l|l|l|l|}
\hline No & Perkembangan & f & \% \\
\hline 1 & Meragukan & 13 & $38,2 \%$ \\
2 & Sesuai & 21 & $61,8 \%$ \\
3 & Menyimpang & - & - \\
\hline \multicolumn{2}{|c|}{ Jumlah } & \multicolumn{2}{|c|}{34} \\
\hline
\end{tabular}

Berdasarkan tabel diatas diketahui bahwa lebih dari sebagian $(61,8 \%)$ balita dari responden mempunyai perkembangan sesuai di Posyandu Serunai VII Kelurahan VI Suku Wilayah Kerja Puskesmas Tanah Garam.

\section{b. Hasil Bivariat}

Hubungan Pemberian Stimulasi dengan Perkembangan Balita Distribusi Frekuensi Responden Berdasarkan Hubungan Pemberian Stimulasi dengan Perkembangan Balita di Posyandu Serunai VII Kelurahan VI Suku Wilayah Kerja Puskesmas Tanah Garam Kota Solok

\begin{tabular}{|l|c|c|c|c|c|c|}
\hline \multirow{2}{*}{$\begin{array}{c}\text { Pemberian } \\
\text { Stimulasi }\end{array}$} & \multicolumn{6}{|c|}{ Perkembangan Balita } \\
\cline { 2 - 7 } & \multicolumn{2}{|c|}{ Meragukan } & \multicolumn{2}{|c|}{ Sesuai } & \multicolumn{2}{c|}{ Total } \\
\cline { 2 - 7 } & $\mathbf{f}$ & $\mathbf{\%}$ & $\mathbf{f}$ & $\mathbf{\%}$ & $\mathbf{F}$ & $\mathbf{\%}$ \\
\hline Diberikan & 5 & $22,7 \%$ & 17 & 77,3 & 22 & $64,7 \%$ \\
\hline Tdk Diberikan & 8 & $66,7 \%$ & 4 & 33,3 & 12 & $35,2 \%$ \\
\hline Jumlah & & & & & $\mathbf{3 4}$ & $\mathbf{1 0 0}$ \\
\hline$P=0,025$ & \multicolumn{4}{c|}{ OR $=6,8$}
\end{tabular}

Hasil analisis antara pemberian stimulasi dengan perkembangan balita didapat lebih dari sebagian $(66,7 \%)$ yang tidak memberikan stimulasi mengalami perkembangan yang meragukan. Sedangkan secara statistik diperoleh $p$ value $=0,025<0,05$ yang artinya ada hubungan yang bermakna antara yang tidak memberikan stimulasi dengan perkembangan balita yang meragukan di Posyandu Serunai VII Kelurahan VI Suku Wilayah Kerja Puskesmas Tanah Garam. 


\section{Pembahasan}

\section{Hubungan Pemberian Stimulasi dengan Perkembangan Balita di Posyandu Serunai VII Kelurahan VI Suku Wilayah Kerja Puskesmas Tanah Garam Kota Solok}

Hasil analisis antara pemberian stimulasi dengan perkembangan balita didapat lebih dari sebagian $(66,7 \%)$ yang tidak memberikan stimulasi mengalami perkembangan yang meragukan. Sedangkan secara statistik diperoleh $p$ value $=0,025$ $<0,05$ yang artinya ada hubungan yang bermakna antara yang tidak memberikan stimulasi dengan perkembangan balita yang meragukan. Stimulasi adalah perasangan yang datangya dari lingkungan di luar individu anak, anak yang lebih banyak mendapatkan rangsangan stimulus cenderung lebih cepat berkembang.

Stimulus juga berfungsi sebagi penguat, memberikan stimulus yang berulang dan terus menerus pada setiap asfek perkembangan anak berarti anak telah mendapatkan kesempatan untuk tumbuh dan berkembang secara optimal.

Kenyataan yang ditemui dilapangan lebih dari sebagian $(66,7 \%)$ yang tidak memberikan stimulasi mengalami perkembangan yang meragukan, hal ini dikarenakan masih adanya responden yang belum memahami atau mampu melakukan stimulasi kepada anaknya sesuai dengan perkembangan usianya di dukung juga lebih dari sebagian responden mempunyai pengetahuan menegah dan dasar.

\section{Penutup}

Berdasarkan hasil penelitian yang dilakukan terhadap 34 responden, diketahui bahwa lebih dari sebagian $(64,7 \%)$ responden memberikan stimulasi perkembangan pada balita, lebih dari sebagian $(61,8 \%)$ balita dari responden mempunyai perkembangan sesuai dan Hasil analisis antara pemberian stimulasi dengan perkembangan balita didapat lebih dari sebagian $(66,7 \%)$ yang tidak memberikan stimulasi mengalami perkembangan yang meragukan. Sedangkan secara statistik diperoleh $p$ value $=0,025<0,05$ yang artinya ada hubungan yang bermakna antara yang tidak memberikan stimulasi dengan perkembangan balita yang meragukan.

\section{Daftar Pustaka}

Ambarwati. 2015. Asuhan Keperawatan Bayi dan Balita. Yogyakarta : Cakrawala Ilmu.

Arikunto, S. 2012. Prosedur Penelitian: Suatu Pendekatan Praktek. Jakarta: Rhinneka Cipta

Cahyaningsih, dkk, 2011. Pertubuhan Perkembangan Anak dan Remaja. Jakarta. Trans Info Media.

Depkes RI, 2011. Pedoman Pelaksanaan Stimulasi, Deteksi, dan Intervensi Dini Tumbuh Kembanh Anak. Jakarta

Hidayat A, 2012. Pengatar Ilmu Keperawatan Anak,. Jakarta : Salemba

Kemenkes, 2016. Situasi Balita Pendek. Jakarta

Notoatmodjo. S. 2012. Metodologi Penelitian Kesehatan. Jakarta. Rineka Cipta.

Rikesda, 2013. Riset Kesehatan Dasar. Jakarta.

Rahayu, sunarsih, 2014. Pertumbuhan dan Perkembangan Balita di Posyandu Skripsi tidak dipublikasi.

Ranuh, 2013. Beberapa Catatan Kesehtan Anak. Jakarta : Sugeng Seto

Soetjiningsih, 2012. Tumbuh Kembang Anak. Jakarta : EGC. 